- mu słowo Eliasza zapowiadające karę śmierci za szukanie u Baala pomocy (2 Krl 1, 5-8). Eliasz jest przekonany, że Jahwe, a nie Baal, rozporządza życiem, i to przedstawi narrator w $1 \mathrm{Krl} \mathrm{17,} \mathrm{17-}$ 24. Chociaż motyw jest obcy, treść opowiadania odpowiada jednak w pełni orędziu Eliasza.

To wszystko odnosi się także do innych opowiadań o cudach. W $1 \mathrm{Krl} \mathrm{17,10-15} \mathrm{jest} \mathrm{zapowiedź} \mathrm{Eliasza,} \mathrm{że} \mathrm{nikt} \mathrm{nie} \mathrm{zginie} \mathrm{z} \mathrm{gło-}$ $\mathrm{du}{ }^{62}$. Tutaj nawet sam motyw pochodzi $\mathrm{z}$ orędzia proroka. W $2 \mathrm{Krl}$ 1, 10-14 późniejszy narrator używa motywu ognia $z$ nieba, który to motyw znalazł się w opowiadaniu o sądzie na górze Karmel. Widać z tego, jak ważną rolę pełniła teologizacja tradycji Eliasza.

W oryginalnej tradycji Eliasza możemy wyróżnić historyczne dzialanie proroka na rzecz obrony kultu monoteistycznego i starego prawa izraelskiego. Do tej tradycji należą także opowiadania o cudach, w których odzwierciedliło się dość dużo z orędzia proroka i jego nieustraszonych czynów.

Erfurt

KS. GEORG HENTSCHEL

82 Por. G. Hents chel, dz. cyt. 200 n.

Ks. Jerzy Chmiel

\title{
POJĘCIE I ROLA KERYGMATU W PIERWOTNYM KOŚCIELE
}

\section{DIACHRONIA POJECIA KERYGMATU}

Pojęcie kerygmatu w egzegezie i teologii biblijnej pojawiło się w latach 1920-stych w kontekście zarysowujących się podówczas badań historii form Nowego Testamentu (Formgeschichte) ${ }^{1}$. Kerygmatem nazwano krótkie, syntetyczne ujęcie najstarszego przepowiadania śmierci i zmartwychwstania Jezusa. M. Dibelius tak określił kerygmat: „Kerygma - die Verkündung von Jesus Christus - wird in ein paar kurzen Sätzen zusammengefasst, Wichtiges wird aus dem Alten Testament belegt, zur Busse und Bekehrung dania, lecz o treść tego przepowiadania, tak jak to $\mathrm{w}$ tym samym sensie używa greckiego terminu kêrygma św. Pawel w 1 Kor 1,21:

$1 \mathrm{Na}$ temat historii pojęcia kerygmatu zob. więcej: $\mathrm{H}$. Ott, w: RGG ${ }^{3}$ III, 1250-54. G. E beling, Theologie und Verkündigung, Tübingen "1963, 109-14. J. Roloff, Das Kerygma und der irdische Jesus, Berlin 1973, $9-24$. 
,spodobalo się Bogu przez glupstwo przepowiadania (tou kêrygmawird aufgefordet" ${ }^{2}$. Chodzi tu więc nie o sam proces przepowiatos) zbawić wierzacych". W tym lkontekścic zaczęto mówić o „,formułach kerygmatycznych", jak np. w 1 Kor 15, 3-5.

$\mathrm{Z}$ biegiem czasu pojęcie kerygmatu zaczęło ulegać pewnej proliferacji semantycznej. I tak termin ,kerygmatyczny" mial oznaczać sposób ujmowania przez pierwszych chrześcijan postaci i misji Jezusa. W tym znaczeniu kerygmat chrystologiczny przeciwstawiano pojęciu historyczności, czego klasycznym przykładem jest tytul zbiorowej pracy w latach 1960 -tych pod redakcją H. Ristowa i K. Matthiae: Der historische Jesus und der kerygmatische Christus.

W związu z analizami morfokrytycznymi tekstu nowotestamentalnego zaczęto kerygmat traktować jako ustny przekaz gatunku literackiego w odróżnieniu od katechezy, parenezy, didache. Stąd też zrodziło się tîumaczenie terminu kêrygma jako ,przepowiadanie misyjne" (J. Schmitt: „prédication missionnaire") skierowane ad extra, do pogan.

Zaczęto dalej traktować kerygmat jako samo jądro przepowiadania starochrześcijańskiego - niejako pars pro toto - przepowiadania pojętego jako całość przekazu apostolskiego (paradosis). Można więc mówić o kerygmacie Dziejów Apostolskich, Pawłowym czy Ewangelii. W tym znaczeniu kerygmat zyskał też rangę normy i kryterium przepowiadania apostolskiego (H. Schlier uważa kerygmat ,als normative apostolische Paradosis").

Osobny rozdział pojęcia kerygmatu stworzył Rudolf Bultmann do tego stopnia, że jego teologię i hermeneutykę biblijną można nazwać - i tak się ją istotnie określa - teologią kerygmatu.

Trawestując słowa Ewangelii - według Bultmanna ,in principio erat kerygma". Bultmann wprawdzie nie neguje ciągłości rzeczowej i chronologicznej między Jezusem prorokiem z Nazaretu a Chrystusem kerygmatycznym, ale sądzi, że kerygmat nie powstał z życia Jezusa ani też nie szuka oparcia w tym życiu. Kerygmat jest odpowiedzią Boga na pytanie człowieka: w Ukrzyżowanym Jezusie Bóg wypowiada swoje zdanie o niewystarczalności człowieka i ofiaruje swoją wolę przebaczenia i życia autentycznego dla każdego, kto zgadza się umrzeć dla siebie samego, ażeby żyć z Bogiem i w Bogu. Kerygmat w ujęciu Bultmanna nie jest już tylko nauczaniem zarówno treściowo, jak i formalnie, lecz staje się wydarzeniem słowa, miejscem zbawienia. Wiąże się z wiarą, której trzeba być posłusznym, i ta wiara, a nie poszukiwania historyczne, jest kryterium przyjęcia kerygmatu.

Bultmann zburzył strukturę formalną kerygmatu w znaczeniu tradycyjnym jako zbioru podstawowych formul wiary. Formuły wia-

2 Die Formgeschichte des Evangeliums, Tübingen ${ }^{5} 1966,15 n$. 
ry zostały wyrażone, według niego, językiem mitycznym, który trzeba odmitologizować (słynny postulat demitologizacji), to znaczy adaptować do mentalności współczesnego człowieka. W kerygmacie interesuja nas nie formuły, lecz te elementy, które odnoszą nas do Boga w dialogu interpersonalnym. Kerygmat zatem jest wydarzeniem wiary dla naszego życia, które to wydarzenie zaczęło się wprawdzie w przepowiadaniu Jezusa (dlatego Bultmann zajmuje się w swojej Geschichte der synoptischen Tradition rekonstrukcją przepowiadania Jezusa), ale swoją ostateczną formę uzyskało w przepowiadaniu apostolskim i trwa w przepowiadaniu Kościoła ". Bultmann zatem przekształcił niejako pojęcie kerygmatu w osobna kategorię psychoreligijną (Anrede) i oderwał go od podłoża historyczno-kulturalnego.

Reakcja na takie stanowisko nie dała długo na siebie czekać, E. Käsemann w swoim, historycznym już wykładzie w Marburgu w 1953 roku na temat Jezusa historycznego ${ }^{4}$ stwierdził, że nie można odrywać kerygmatu Kościoła od kerygmatu Jezusa. W tłumaczeniu stopnia zainteresowania się pierwszych chrześcijan ziemskim Jezusem pojawiają się rozróżnienia na kręgi kulturowe: mówi się o kerygmacie hellenistycznym i palestyńskim. Podejście jednak autorów jest różne, a ich wnioski częstokroć się sobie nawzajem sprzeciwiają. Tak np U. Wilckens sądzi, że gminy hellenistyczne z Pawłem włącznie przepowiadały kerygmat o Chrystusie, który nie uwzględniał nauczania i działalności Jezusa - ten aspekt należał do judeochrześcijan w Palestynie. Dopiero później tradycje o Jezusie przeniknęly do kręgów hellenistycznych ${ }^{5}$. Jednak G. Ebeling zauważa, że kręgi hellenistyczne docenialy biograficzną prezentację Jezusa ${ }^{6}$.

Trudności, na jakie napotykają wzmiankowane tezy, wynikają stąd, iż akcentując różnice religijne pomiędzy judaizmem palestyńskim a hellenistycznym, nie uwzględnia się tego, że kuitura helienistyczna wcześniej i głębiej przeniknęła życie żydowskie, njż to by się mogło wydawać. Chociaż helleniści tworzyli osobną grupę w Dziejach Apostolskich, jest wysoce dyskusyjne, czy te dwie grupy - hellenistów i judeochrześcijan - należy sobie diametralnie przeciwstawiać $\mathrm{w}$ okresie nowotestamentalnym ${ }^{7}$.

$3 \mathrm{Na}$ temat opracowań o teologii kerygmatu Bultmanna por. L. M a$1 \mathrm{evez}$, Jésus de l'histoire et interprétation du kérygme, w: ,Nouvelle Revue Théol." 91 (1969) 785-808.

${ }_{4}$ Das Problem des historischen Jesus, w: ,Zeitschrift für Theologie und Kirche" 51 (1954) 125-153.

5 Tradition de Jésus et kérygme du Christ: la double histoire de la tradition au sein du christianisme primitif, w: „Revue d'histoire et de philosophie religieuses" 47 (1967) $1-20$.

6 Theologie und Verkündigung, Tübingen 21963, 109-114.

7 Por. M. H e ngel, Judentum und Hellenismus. Studien zu ihrer Begegnung unter besonderer Berücksichtigung Palästinas bis zur Mitte 
Należy jeszcze zwrócić uwagę na badania nad kerygmatem pojętym jako recytacja słów Pana. Już pod koniec XVIII w. J. G. Herder zwrócil uwagę biblistów na przepowiadanie ustne, czyli na pierwotną katechezę. Była to raczej intuicja niż wynik badań, intuicja, która w wieku Oświecenia i początków krytyki biblijnej nie została podchwycona. Dużo nowych elementów wniosły badania porównawcze nad tradycją judaistyczna i jej mechanizmami, prowadzone w okresie międzywojennym; że wymienimy takie nazwiska, jak: Th. Soiron, P. Fiebig, C. Lattey, E Levesque, J. Huby, M. Jousse czy R. Pautrel ${ }^{8}$.

Specjalnie jednak na tym polu zasłużyła się szkoła skandynawska. Nowy punkt wyjścia zapoczątkował $H$. Riesenfeld w swoim głośnym wystąpieniu kongresowym w 1957 r. ${ }^{9}$. Kerygmat pierwochrześcijański sięga do własnej świadomości mesjańskiej Jezusa poprzez recytację tradycji o Jezusie - oto wniosek wysnuty przez egzegetę szwedzkiego. „Jezus jest nie tylko przedmiotem późniejszej wiary, która ze swej strony powoduje rozwój ustnej i pisemnej tradycji, ale jako Mesjasz i Nauczyciel jest przedmiotem i podmiotem tradycji autorytatywnych i świętych słów, które On sam stworzył i powierzył swoim uczniom celem ich późniejszego przekazu, pomiędzy swoją śmiercią a paruzją" 10. U podstaw kerygmatu leży zatem, według Riesenfelda, ,recytacja tradycji o Jezusie jako święte słowa Nowego Przymierza" 11.

Stanowisko Riesenfelda zostało poparte przez jego ucznia B. Gerhardssona ${ }^{12}$, ktćry przeprowadził drobiazgowe studia późniejszych rabinistycznych metod przekazywania nauczania i wykazali, że były one używane przez samego Jezusa. W oparciu o te badania i na podstawie badań tradycji ludowych $\mathrm{T}$. Boman ${ }^{13}$ twierdzi, że tradycja kerygmatyczna, głoszona przez Apostołów, była odrębna od tradycji ewangelicznych, głoszonych przez specjalne grupy narratorów, którzy podlegali Apostołom i prorokom. Lecz istnienie takich grup

des 2. Jhs. v. Chr. (WUNT 10), Tübinger 21973. I. H. M a rs hal1, Palestinian and Hellenistic Christianity: Some Critical Comments, w: „New Test. Studies" 19 (1972-73) $271-87$.

8 Zob. szerzej na ten temat: J. Schmitt, La prédication apostolique. Les formes, le contenu, w: Où en sont les études bibliques, Paris $1968,107-133$.

9 The Gospel Tradition and its Beginnings, w: Studia Evangelica, t. I, Berlin 1959, 43-65. Tekst został wydany osobno w 1957 r., zaś później powtórzony w: The Gospel Tradition, Oxford 1970, 1-30.

${ }_{10}$ The Gospel Tradition, Oxford 1970, 29.

11 Tamże, 21.

1. Memory and Manuscript: Oral Tradition and Written Transmission in Rabbinic Judaism and Early Christianity, Uppsala 1961. Tenże, Tradition and Transmission in Early Christianity, Uppsala 1964. Tenże, Préhistoire des Evangiles, Paris 1978.

${ }_{13}$ Die Jesusüberlieferung im Lichte der neueren Volkskunde, Göttingen 1967. 
narratorów jest hipotezą gratis data, podobnie jak przyjęcie dwóch czynności transmisji tradycji: kerygmatycznych i ewangelicznych. Niemniej jednak to, co jest najciekawsze dla nas w powyższych badaniach, to rehabilitacja kerygmatu jako przekazu o Jezusie, biorącego początek od samego Jezusa (de Jesu ab ipso Jesu).

Nie brak autorów ${ }^{14}$, którzy dopatrują się istnienia motywacji etycznych w kształtowaniu się kerygmatu: do przepowiadania misjonarzy trzeba było przykładu naśladowania Jezusa dla życia chrześcijan. Istotnie, można znaleźć ślady takiej motywacji ì 1 Kor 11,1 czy 1 Tes 1, 6, lecz u podstaw kerygmatu leży proces przekazu informacji o faktach zbawienia i nauczania Mesjasza dla obudzenia wiary.

Zatrzymaliśmy się dłużej nad rozwojem pojęcia kerygmatu w poszukiwaniach współczesnej egzegezy, ażeby $z$ jednej strony podkreślić złożoność zagadnienia, a z drugiej zaś wykazać, że nie można mówić o kerygmacie w pierwotnym Kościele w oderwaniu od osoby i działalności Jezusa Chrystusa. Należy obecnie z kolei zająć się strukturą kerygmațu, jaki dotarł do nas w zapisie nowotestamentalnym.

\section{STRUKTURA KERYGMATU APOSTOLSKIEGO}

Przyjmujemy tutaj punkt widzenia C. H. Dodda, który przez kerygmat rozumie publiczne przepowiadanie chrześcijaństwa światu pogańskiemu, wyróżniając w ten sposób kerygmat od parenezy i jej form, jak: didache, paraklesis, homilia ${ }^{15}$. Jak nie bez humoru zauważa Dodd, według Pawła spodobało się Bogu zbawić człowieka przez „kêrygma”, a nie przez „didachê” (1 Kor 1, 21).

Zgadzając się na to rozróżnienie zarówno formalne, jak i treściowe, kerygmatu od didache, musimy jednak uczynić zastrzeżenie, że byłoby błędem metodologicznym przeciwstawiać sobie te dwa pojęcia $\mathrm{w}$ pierwotnym nauczaniu apostolskim ${ }^{16}$. Wydaje się bowiem, że w praktyce te dwie formy głoszenia słowa Bożego utożsamiały się, zwłaszcza w Kościele późniejszym.

Pierwszym zadaniem kerygmatu było niejako uderzenie słuchacza (P. Benoit określa to jako „une prédication de choc”), podanie

14 Por. A. M. Ramsey, The Gospel and the Gospels, w: Studia Evangelica, I, Berlin 1959, 35-42. E. J. Tinsle y, The Imitation of God in Christ. An Essay in the Biblical Basis of Christian Spirituality, 1960. E. L a rs s o n, Christus als Vorbild, Lund 1962. H. D. B e tz, Nachfolge und Nachahmung Jesu Christi im Neuen Testament, Tübingen 1967.

15 The Apostolic Praeching and its Developments, London ${ }^{41970 . ~ I ~ w y d . ~}$ ukazało się w 1936 r. Opieram się na włoskim przekładzie: La predicazione apostolica e il suo sviluppo, Brescia 1973, 9n.

16 Por. J. I. H. M cDonald, Kerygma and didache. The articulation of the earliest Christian message (Soc. for NT Studies, mon. ser. 37), London 1979. 
światu wstrząsającej wieści, że Bóg działa w historii ludzkości w sposób wszechmocny przez osobę Jezusa: nikt nie może pozostać obojętny wobec tego działania bożego, trzeba się poddać, trzeba przyjąć oczywistość owych faktów poświadczonych przez znaki, trzeba uwierzyć, trzeba się nawrócić ${ }^{17}$. Psychologiczną bazą kerygmatu była nadzieja, jaką on niósł pogańskiemu światu pozbawionemu nadziei ${ }^{18}$.

Powyższe stwierdzenia - wbrew temu, co by się mogło wydawać - mają niezmiernie ważne znaczenie dla poznania typologii i struktury kerygmatu. Mamy bowiem tutaj do czynienia ze świadectwem oficjalnym, apostolskim na temat Jezusa Chrystusa, świadectwem, które znajduje się u podstaw jedności wszystkich pism Nowego Testamentu ${ }^{19}$. Można zgodzić się ze zdaniem A. Huntera, że ,schemat kerygmatu rzutuje na cały Nowy Testament, udzielając mu w ramach różności głębokiej i istotnej jedności" ${ }^{20}$. W niniejszym artykule ograniczymy się do typologii kerygmatu w Dziejach Apostolskich i w Listach Pawłowych.

1. Kerygmat jerozolimski

Już ponad 40 lat temu Dodd postawił tezę, że mowy Piotra w Dziejach pochodzą z nauczania Kościoła jerozolimskiego, używającego języka aramejskiego, $\mathrm{z}$ okresu o wiele wcześniejszego od powstania księgi ${ }^{21}$. Teza ta spotkała się z gwaltowną reakcją, zwłaszcza autora doskonałego skądinąd komentarza do Dziejów, E. Haenchena ${ }^{22}$. Z perspektywy jednak badań i opinii egzegetów można zgodzić się na to, że jakkolwiek mowy apostolskie pod względem redakcyjnym są dziełem Eukasza, to jednak odzwierciedlają one pierwotny kerygmat, na co wskazują autorytety Apostołów, zwłaszcza Piotra ${ }^{23}$.

17 Por. P. Benoit, Les origines du Symbole des Apôtres dans le Nouveau Testament, w: Exégèse et théologie, Paris 1961, t. II, 193-211.

18 Por. D. Stanle y, La prédication primitive: schéma traditionnel, w: „Concilium” n. 20 (1966) 79-88.

19 C. F. D. Moule, Jesus in New Testament Kerygma, w: O. Böcher - K. Ha a cker (ed.), Verborum Veritas. Festschrift für G. Stählin, 1970, 15-26 jest zdania, że Paweł wziął ze sobą Marka: „He took, as it were, a ,gospel source" with him, in the form of a person acquainted with the facts" (tamże, 25).

20 Introducing New Testament Theology, London 1957, 68.

21 Dz. cyt., 23.

22 Zob. szerzej J. Chmiel, Tradycja apostolska a redakcja Eukasza w dziejach Apostolskich, w: „Analecta Cracoviensia” 8 (1976) 125-131.

23 Por. D. Stanley, art. cyt., 80. - F. F. Bruce, The Speeches in Acts - Thirty Years After, w: R. B anks (ed.), Reconciliation and Hope: New Testament Essays on Atonement and Eschatology Presented to L. L. Morris, 1974, 53-68. 
Możemy więc - za przykładem Dodda - mówić o kerygmacie jerozolimskim w Dziejach Apostolskich, jakkolwiek dotąd egzegeci nie zgodzili się co do stopnia aktualizacji przez autora Dziejów archaicznego materiału kerygmatycznego i nie wiadomo, czy kiedykolwiek co do tego się zgodzą. W szczególności jednak mowy Piotra w I części Dziejów są - według wyrażenia P. Benoit - miejscem uprzywilejowanym (,un lieu privilégié”) kerygmatu jerozolimskiego 24. Do mów Piotra trzeba dołączyć jeszcze mowę Pawła w Antiochii Pizydyjskiej ( $\mathrm{Dz}$ 13, 16-41), która w pewien sposób rozwija schemat poprzednich mów ${ }^{25}$.

Zauważono, że owe mowy zawierają pewne wspólne elementy strukturalne, która nawzajem się uzupełniają i tworzą jakiś obraz kerygmatu jerozolimskiego. Oto te wspólne elemeaty:

1) Czas wypełnienia: proroctwa Starego Testamentu spełniaja się (Dz 2, 16; 3, 18. 24).

2) Zarys biografii Jezusa na podstawie zapowiedzi skrypturystycznych:

a) pochodzenie od Dawida ( $\mathrm{Dz} 2,30 \mathrm{n})$,

b) działalność Jezusa z Nazaretu ( $\mathrm{Dz} 2,22 ; 3,22)$,

c) śmierć ( $\mathrm{Dz}$ 2, 23),

d) zmartwychwstanie ( $\mathrm{Dz} 2,24 \mathrm{nn} ; 3,15 ; 4,10$ ).

3) Na mocy zmartwychwstania Jezus został wywyższony na prawicy Boga jako mesjański wódz nowego Izraela (Dz 2, 33nn; 3, 13; $4,11 ; 5,31)$.

4) Duch Swięty w Kościele jest znakiem mocy i chwały Chrystusa (Dz 2, 33; 5, 32).

5) Era mesjańska nastanie wkrótce po powtórnym przyjściu Jezusa Chrystusa (Dz 3, 20n). Inny wariant tej prawdy kerygmatycznej mówi o Chrystusie - sędzi żywych i umarłych (Dz 10, 42).

6) Kerygmat kończy się zawsze wezwaniem do pokuty, co jest owocem przebaczenia i darem Ducha oraz obietnica zbawienia, to jest życia wiecznego dla tych, którzy wejdą do społeczności wybranych.

Widać z tego, iż naczelną zasadą, na której zbudowany został kerygmat jerozolimski, jest wypełnienie się zapowiedzi mesjańskich. Można w tym dopatrywać się nawiązania do zasady egzegezy rabinistycznej, która wszystkic proroctwa Starego Testamentu odnosiła

24 Por. J. Chmie 1, Interpretacja Starego Testamentu $w$ kerygmacie apostolskim o zmartwychwstaniu Jezusa. Studium hermeneutyczne, Kraków 1979.

${ }_{25}$ Por. J. Schmitt, Kerygme pascal et lecture scripturaire dans l'instruction d'Antioche (Act. 13, 23-37), w: J. K r e m er (réd.), Les Actes des Apôtres. Tradition, rédaction, théologie (Bibl. EThL 48), Gembloux Leuven 1979, 155-67. 
do „dni Mesjasza”, to jest do tego czasu, w którym Bóg po wiekach długiego oczekiwania miał nawiedzić swój lud, ażeby urzeczywistnić w pełni ową jedność zapoczątkowaną niegdyś w historii. Ale jest to też niewątpliwie — a może przede wszystkim - wyraz rosnącej coraz to bardziej wśród pierwszych uczniów Chrystusa świadomość ciągłości, continuum objawiania się Boga, ciągłości procesu historycznego zapoczątkowanego w ludzkości objawieniem się Boga Abrahama, Izaaka i Jakuba aż po objawienie się przez Sługę swego, Jezusa ( $\mathrm{Dz} 3,13$; por. Hbr 1, 1-2). Na ten aspekt historycznej świadomości kerygmatu apostolskiego warto zwrócić uwagę; nie jest to bowiem wykładnik mitologizującego procesu tak charakterystycznego dla kultur starożytnych (co nie wyklucza obecności pewnych elementów mitycznych na prawach językowo-literackich), lecz mamy tutaj do czynienia $\mathrm{z}$ procesem historycznego poznawania faktów zbawienia.

2. Kerygmat Paw 10 w y

Dzieje Apostolskie jakkolwiek są - jak powiedzieliśmy - miejscem uprzywilejowanym dla poznania kerygmatu, nie są jednak jedynym o nim świadectwem. Listy apostolskie również odzwierciedlają pierwotny kerygmat, choć w sposób mniej systematyczny. Weźmiemy tutaj pod uwagę tylko Corpus Paulinum, nie poruszając innych listów apostolskich.

Elementy kerygmatyczne w listach Pawłowych są łatwo rozpoznawalne $\mathrm{z}$ ich zwięzłości, stylu prostego i enuncjacyjnego, częstokroć rytmicznego. Niejednokrotnie kontekst zdradza ich pochodzenie, względnie występują formuły wskazujące na przekaz wiary, jak np. w 1 Kor 15, 1nn; paredôka - parelabon. Paweł mówiąc o prawdach kerygmatycznych przypomina, że pochodzą one z jego Ewangelii (por. $\mathrm{Rz} 2,16 ; 2 \mathrm{Tm} 2,8$ ).

Jesteśmy w stanie $\mathrm{z}$ porozrzucanych w poszczególnych listach twierdzeń kerygmatu zrekonstruować jego całość w przekazie Pawła. Schemat taki przedstawia się następująco:

1) Proroctwa Starego Testamentu wypełniły się i

2) nowa era nastała z przyjściem Jezusa.

3) ' On pochodzi z rodu Dawida,

4) umarł według Pism,

5) ażeby nas zbawić od zła obecnego czasu.

6) Został pogrzebany i

7) trzeciego dnia zmartwychwstał według Pism.

8) Wyniesiony na prawicę Boga

9) jako Jego Syn i Pan żywych i umarłych

10) przyjdzie znów jako sędzia i zbawiciel ludzi. 
Porównując powyższy schemat kerygmatu Pawłowego z kerygmatem jerozolimskim w Dziejach stwierdzamy istotną tożsamość głoszonych prawd w pierwotnym Kościele. Przepowiadanie Pawła pokrywa się z przepowiadaniem Apostołów. Zwróćmy jednak uwagę na pewne różnice pomiędzy kerygmatem Pawłowym a jerozolimskim, co pozwoli nam na wysnucie pewnych wniosków.

a) Kerygmat jerozolimski zwraca się do danych biograficznych Mesjasza, akcentując Jego słowa i czyny, przepowiadanie i cuda, podczas gdy kerygmat Pawła wydaje się abstrahować od tych danych. Trzeba jednak pamiętać, że potwierdzeniem autentyczności przekazu wiary była w pierwszym rzędzie nie pamięć, jaką Apostołowie zachowali o słowach i czynach Jezusa, lecz sens, jaki Kościół dawał osobie Jezusa i Jego dziełu zbawczemu. Paweł znał naukę Jezusa z Jego przypowieści i innych słów, nade wszystko jednak miał świadomość, że jego autorytet jako głosiciela Ewangelii pochodzi ze znajomości ,zamysłu Chrystusa" (nous Christou: 1 Kor 2, 16). Stąd pewność Pawła co do czytania publicznie jego listów (por. 1 Tes 5, 27; Kol 4, 16); przepowiadanie Apostoła jest budowaniem na fundamencie Jezusa Chrystusa. Jest to zatem wyraz świadomości, że głoszenie kerygmatu o Jezusie Chrystusie nie jest mechanicznym powtarzaniem słów Mistrza, lecz ich rozumieniem i wyjaśnianiem.

b) Kerygmat jerozolimski nie nazywa Chrystusa „Synem Bożym". Tytuły chrystologiczne zostały tam wzięte raczej z tekstów Deuteroizajaszowych: Chrystus jest świętym i sprawiedliwym sługą Boga. Godne uwagi, że Dzieje właśnie Pawłowi jako pierwszemu przypisują głoszenie Jezusa Synem Bożym. Myśl, że Jezus jako Mesjasz jest Synem Bożym, znajduje się mocno zakorzeniona u Synoptyków, których źródła nie zależały od wpływów Pawła, podobnie jak i formuła chrystologiczna $w \mathrm{Rz} 1,1-4$ nie jest pochodzenia Pawłowego. Zwrot „Syn Boży pełen mocy” z Listu do Rzymian jest bliski formule „Pan i Mesjasz” w Dziejach. Możemy zatem mówić nie tyle o różnicach terminologicznych, ile o rozwoju rozumienia osoby Jezusa.

c) Kerygmat $z$ Dziejów nie twierdzi, że Chrystus umarł za nasze grzechy. Odpuszczenie grzechów jest wynikiem życia, śmierci i zmartwychwstania Jezusa, lecz nie został wyrażony w Dziejach ścisły związek pomiędzy śmiercią Jezusa a odpuszczeniem grzechów. Paweł mówiąc, że Jezus umarł za nasze grzechy, powołuje się na to, co był otrzymał. Jest to zatem element pierwotny kerygmatu apostolskiego. Kiedy bowiem $w$ tym kerygmacie Chrystus został nazwany Sługą według określenia Deuteroizajasza, to otwiera się droga do dalszej interpretacji Iz 53 w kontekście ekspiacyjnej roli śmierci tegoż Sługi. Warto przypomnieć, że Dodd wysunął ciekawą hipotezę, iż prawda o śmierci Jezusa za grzechy została wypraco- 
wana w szkole Szczepana i Filipa - na co wskazywałby tekst $\mathrm{Dz}$ 8, 32-35-z którą to szkołą Paweł, wydaje się, był w kontakcie ${ }^{26}$.

d) Kerygmat jerozolimski nie wskazuje na fakt, że Chrystus chwalebny wstawia się za nami, która to prawda jest tak mocno podkreślona w $\mathrm{Rz} 8,34 \mathrm{w}$ kontekście formuły kerygmatycznej. Nie wydaje się jednak, ażeby ta prawda była pochodzenia Pawłowego, skoro występuje ona w Hbr 7, 25, a także prawdopodobnie w Mt 10, 32. Formuła o wstawiennictwie zmartwychwstałego Chrystusa jest tylko wariantem prawdy kerygmatu z Dziejów o odpuszczeniu grzechów „w imię Jego" (tj. Chrystusa).

Przeprowadzone porównanie pomiędzy kerygmatem jerozolimskim a Pawłowym zarówno od strony tożsamości merytorycznej, jak i od strony różnic terminologicznych, wskazuje na istotną funkcję kerygmatu w pierwotnym Kościele. Było to głoszenie śmierci i zmartwychwstania Chrystusa w perspektywie eschatologicznej, która nadaje znaczenia tym wydarzeniom Jezusa. Jednocześnie był to pewien proces w przepowiadaniu wiary, który polegał nie na mechanicznym powtarzaniu słów Mistrza, lecz na ich przekazie dynamicznym, to znaczy przekazie regulującym wartości semantyczne przekazywanych informacji w miare interpretacji tychże informacji. Jest to jedyny proces $-z$ punktu widzenia antropologii kulturalnej - zdolny do adekwatnego przekazu myśli. Używamy tutaj pojęcia „dynamiczny” w senșie oryginalnym Dz 4, 33: „Apostołowie $z$ wielka moca (dynamei megalêy) świadczyli o zmartwychwstaniu Pana Jezusa, a wszyscy oni mieli wielka laskę".

Owa „wielka łaska" (charis megalê) to obecność Ducha Swiętego działającego w przekazie wiary i niejako sterującego procesem kerygmatyzacji. Tej obecności Ducha byli świadomi kerygmatycy głoszący Ewangelię: „Dajemy temu świadectwo - mówil Piotr przed Sanhedrynem - my właśnie oraz Duch Swięty, którego Bóg udzielit tym, którzy $M u$ sa postuszni" (Dz 5, 32). Był zatem kerygmat w pierwotnym Kościele procesem charyzmatycznym, pneu matycznym, który wykraczał poza formę literacką przekazu, aby żywe Słowo Boże nie uległo zafałszowaniu, a pamięć o faktach zbawiającego Boga nie stała się formalnym wspominaniem przeszłości.

Można zgodzić się z A. Hunterem, który pisze: „Jakakolwiek byłaby forma literacka Ewangelii, opowiadań historycznych, listów czy Apokalipsy, czy autorem będzie Paweł, Jan czy autor Listu do He-

${ }^{26}$ La pradicazione apostolica, 29. Zob. także M. He nge1, Der stellvertretende Sühnetod Jesu. Ein Beitrag zur Entstehung des urchristlichen Kerygmas, w: "Internationale katholische Zeitschrift Communio" 9 (1980) $1-25 ; 135-147$. 
brajczyków, zawsze odnajduje się schemat kerygmatu" ${ }^{27}$. Kerygmat był więc tym czynnikiem, który zespalał powstające tradycje, zarówno wszystkie pisma Nowego Testamentu, jak i łączył z pismami Starego Testamentu poprzez odwoływanie się do proroctw. Kerygmat był ową $\mathrm{n}$ a uką o $\mathrm{zb}$ awieniu (logos tês sôtêrias), o której mówił żydom i poganom Paweł w Antiochii Pizydyjskiej (Dz 13, 26). Wydaje się, że takie byłoby najtrafniejsze polskie tłumaczenie greckiego pojęcia kêrygma.

Kraków

KS. JERZY CHMIEL,

27 Dz. cyt., 70.

\section{Ks. Adam Odzimek}

\section{LUKASZOWY KERYGMAT O JEZUSIE MĘCZENNIKU}

Ewangelia św. Eukasza, napisana prawdopodobnie po r. $70 \mathrm{w}$ jednej z wielkich metropolii świata hellenistycznego - w Rzymie czy w Aleksandrii - zawiera szczególny obraz Jezusa. Jezus to Kyrios, który jako Zbawiciel objawia dobroć i miłosierdzie Boga. W Łukaszowej relacji o męce Jezusa zawarty jest wyjątkowo bogaty tzw. aspekt personalny ${ }^{1}$. Zdaniem wielu współczesnych egzegetów ${ }^{2}$ przedstawia on Jezusa jako Męczennika. W ten sposób Łk nawiązuje do hellenistycznej i judaistycznej literatury o męczennikach, której bohaterami byli wspaniali mężowie, ofiarujący życie za największe wartości: wiarę, ojczyznę, prawdę, etc. Aby lepiej odczytać treść Łukaszowego kerygmatu o Jezusie-Męczenniku, trzeba nawiązać do wymienionych kręgów piśmiennictwa. Elementy formalne i treściowe tych gatunków literackich pozwalają nie tylko skonfrontować podobieństwa i różnice $\mathrm{z}$ Łukaszowym przedstawieniem męczeństwa Jezusa, ale przede wszystkim zauważyć oryginalność Łukaszowego ujęcia.

Ogólnie zarysowana problematyka zagadnienia mieści zatem w sobie następujące części szczegółowe:

1. Martys w hellenistycznych Aktach męczeńskich

2. Męczennik w judaistycznych opisach męczeństw

3. Jezus jako Męczennik w Eukaszowym opisie męki

4. Oryginalność Łukaszowego kerygmatu.

1 A. Vanhoye, De narrationibus Passionis Christi in evangeli. ognopticis, Romae 1970, 39-41 (mps).

$\therefore$ Np. W. Grundmann, H. Haag, B. Rigaux, F. Gryglewric.. 